\title{
SURGICAL PERSONNEL' ADHERENCE TO ANTIBIOTIC POLICIES
}

\author{
E. Keuleyan ${ }^{1}$, G. Kirov ${ }^{2}$, M. Kondarev ${ }^{2}$, I. Lozev ${ }^{2}$, D. Vezeva ${ }^{3}$, S. Toujarov ${ }^{4}$, N. \\ Smilov ${ }^{4}$ \\ 1) Department of Clinical Microbiology, \\ 2) Clinic of Surgery, \\ 3) Clinic of Anesthesia and Resuscitation, \\ 4) Department of Urology \\ Medical Institute - Ministry of the Interior, Sofia, Bulgaria
}

\section{SUMMARY}

- Objectives. This work aimed at studying the adherence of personnel of the Surgery clinic of our institute to antibiotic policies in place.

- Methods. Antimicrobial resistance surveillance of the alert resistant microorganisms (Staphylococcus aureus (MRSA), Enterobacteriaceae (ESBL-producing), Pseudomonas aeruginosa, MDR); Antibiotic consumption calculation (ABC calc, D. Monnet); Audits of antibiotic prescriptions, and Inquiries - were performed.

- Results. Current antibiotic policies in the Surgery clinic (50-bed) were prepared, discussed and introduced in 2003. Since then, five 3-month audits of antibiotic prescriptions took place. During the last four years (2006-2009), the problem resistant organisms were: MRSA, 10-36\%; ESBL-producing Enterobacteriaceae, 14-23 \%; MDR P. aeruginosa, 30-47 \% and carbapenem-resistant, 0-35\%. Antibiotic consumption was between 47.9 and $61.9 \mathrm{DDD} / 100$ bed-day, and first generation cephalosporins were the top used antibiotics (29.535.2 DDD/100 bed-day). Two inquiries (2007 and 2009) revealed: - a good compliance with the policies, with the exception of the duration of antibiotic prophylaxis, - and a comprehensive knowledge on antibiotics and antibiotic resistance.

- Conclusion. With one exception (the duration of antibiotic prophylaxis) this study revealed good adherence to antibiotic policies, as well as professional attitudes towards the rational use of antibiotics.

Key words: antibiotic stewardship, surgery, audit, inquiry, Bulgaria.

\section{INTRODUCTION}

Nowadays considerations in prescribing antibiotics become more and more important, taking in mind the idea to better cure the patient and to preserve the activity of available antibiotics $[6,7,9,11,13,21]$. In surgery antibiotics are used both as antibiotic therapy of infection and antibiotic prophylaxis (of the surgical site infections). Antibiotic stewardship in a surgical clinic has several elements, related to the instituted antibiotic policies and to the adherence of surgical personnel $[1,4,14,18,19]$.

The objective of the present work was to study the adherence of personnel of the Surgery clinic to antibiotic policies.

\section{MATERIALS AND METHODS:}

- Setting. Medical Institute - Ministry of the Interior is a 350-multiprofile national hospital. Surgery clinic has 50 beds and consists of 3 departments: Abdominal surgery, Thoracic surgery and Septic surgery. During the study period the rate of surgical site infections was between $2.5 \%$ and $3.6 \%$.

- Antimicrobial resistance surveillance. The surveillance of antibiotic resistance is one of the main tasks of the Clinical Microbiology laboratory. It was based on in vitro susceptibility testing of important clinical pathogens by disc diffusion method according to the CLSI, USA - guidelines, 2007.

- Antibiotic consumption. Antibiotic consumption was measured by WHO/ECDC recommended method in DDD/100 bed-day: $\mathrm{ABC}$ calc (D. Monnet).

- Audit of antibiotic prescriptions. The audit of antibiotic prescription is one of the most recommended tools in controlling antibiotic policies (ESGAP, ESCMID). Two different forms to be filled in by clinicians were developed: for Antibiotic therapy- and for Antibiotic prophylaxis in Surgery (SAP).

- Inquiry. Two anonymous inquiries were used to study: - the attitudes towards antibiotics and antibiotic resistance and - the instituted antibiotic policies (multiple choice answers - questions were used).

\section{RESULTS}

Antimicrobial Resistance surveillance in this work covered the last four years (2006-2009) and focused on the three top-alert microorganisms of clinical significance in surgery: Staphylococcus aureus, methicillin - resistant 
(MRSA); microorganisms of the family Enterobacteriaceae - multiple-drug resistant, especially the producers of extended spectrum beta-lactamases (ESBL); multiple-drug resistant (MDR) Pseudomonas aeruginosa. Figures $1-3$ demonstrate the percentage of problem antibiotic resistant organisms in the Surgery clinic during the period from 2006 to 2009:

Fig. 1. Relative rate of MRSA among S. aureus strains ( $\mathrm{n}=139$ ) by year (from 2006 to 2009)

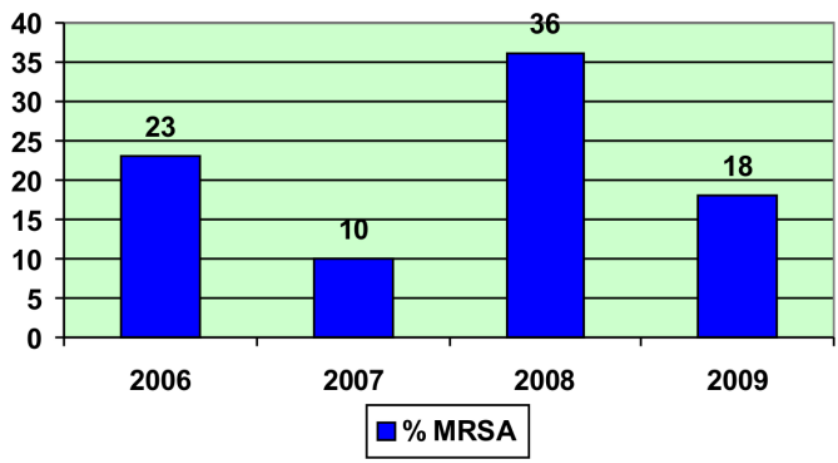

Legend: MRSA, methicillin-resistant S. aureus

Fig. 2. Antibiotic Resistance Surveillance - Fam. Enterobacteriaceae $(\mathrm{n}=268)$

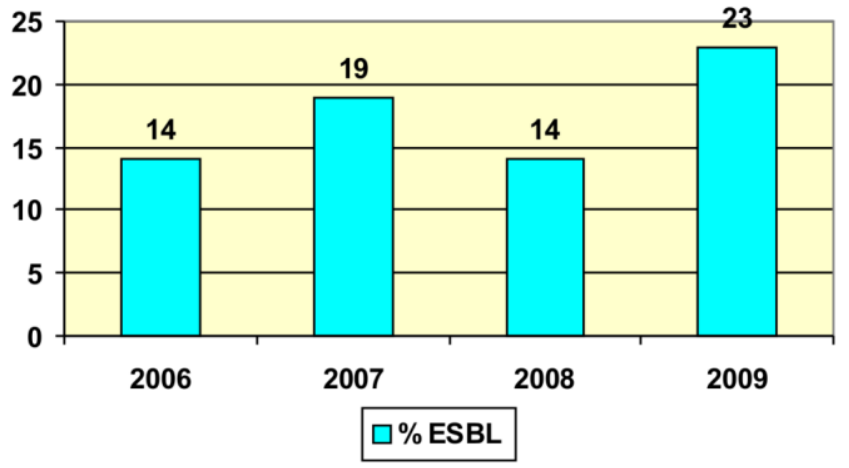

Legend: ESBL: extended-spectrum beta-lactamase

Fig. 3. Antibiotic Resistance Surveillance $-P$. aeruginosa $(\mathrm{n}=51)$

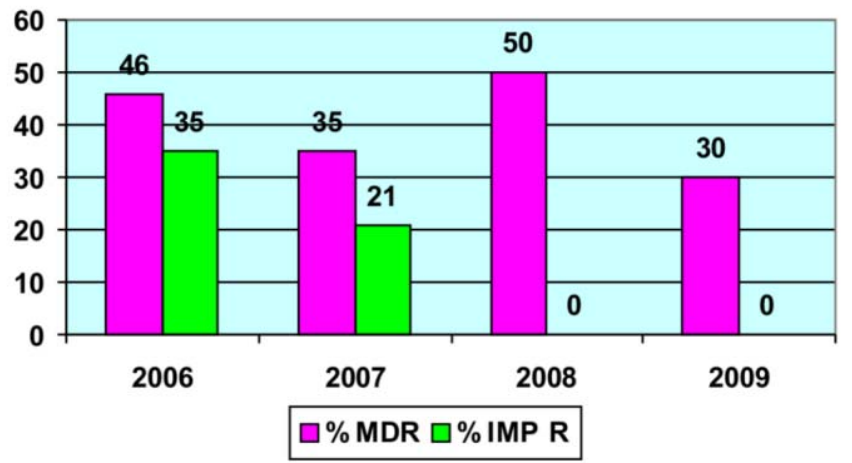

Legend: MDR, multiple drug resistant; IMP R resistant to carbapenems
From the figures 1 to 3 it becomes evident, that the percentage of MRSA strains from surgical infections was between $10 \%$ and $36 \%$, ESBL-producers rate among Enterobacteriaceae was between $14 \%$ and $23 \%$, while the MDR P. aeruginosa were from $30 \%$ to $47 \%$, furthermore, during 2006-2007 several clinical isolates were carbapenemresistant.

Another important data come from the consumption of antibiotics - Table. 1.

Table 1. Antibiotic consumption in DDD/100 bed-day

\begin{tabular}{l|l|l|l|l}
\hline Antibiotics & 2006 & 2007 & 2008 & 2009 \\
\hline Tetracyclines & 0.1 & 0.1 & 0.1 & 0 \\
Penicillins & 2.8 & 5.3 & 4.7 & 4.8 \\
Cephalosporins I & 32.6 & 29.9 & 35.2 & 29.5 \\
Cephalosporins III & 3.3 & 4.7 & 3.8 & 10.0 \\
Cephalosporins IV & 0.3 & 1.3 & 0 & 0.5 \\
Macrolides-L-S & 0.8 & 2.1 & 1.0 & 2.2 \\
Aminoglycosides & 3.2 & 1.4 & 0.7 & 1.8 \\
Fluoroquinolones & 1.5 & 2.1 & 2.2 & 4.2 \\
Imidazoles & 6.8 & 4.5 & 0.1 & 7.6 \\
Others & & & 0.1 & 0.2 SXT, \\
& & & & 0.3 IMP \\
\hline Total & 50.0 & 56.4 & 47.9 & 61.9 \\
\hline
\end{tabular}

Legend: SXT, co-trimoxazole; IMP, imipenem; Llincosamides; S-streptogramins

Table 1. shows that the total antibiotic usage in the Surgery clinic fluctuated from 47.9 to $61.9 \mathrm{DDD} / 100$ bed-day. The most commonly used antibiotics were the cephalosporins of first generation, followed by imidazoles: this corresponds to the spectrum of clinic [26].

In an attempt to study the personnel' attitude and adherence to the antibiotic policies, we performed several 3month audits of antibiotic prescriptions. The first audit was conducted in 2003, before the introduction of current antibiotic policy. The results recorded for Antibiotic prophylaxis in surgery (SAP) - 2003 are listed below: 


\section{REGIMEN PRESCRIBED FOR:}

Gastro-duodenal operations- high risk

Augmentin 3 x $1.2 \mathrm{~g}(\mathrm{n}=4)$

Ampicillin/Sulbactam 3 x $3 \mathrm{~g}$ (1)

Ceftriaxone $2 \times 1 \mathrm{~g}(2)$

Augmentin $3 \times 1 \mathrm{~g}+$ Amikacin $\times 1 \mathrm{~g}(1)$

Cefoperazone $3 \times 2 \mathrm{~g}+$ Amikacin $\times 1 \mathrm{~g}$ (1)

Cefepime 2 x $1 \mathrm{~g}+$ Metronidazole 2 x $1 \mathrm{~g}$ (1)

Biliary tract operations- high risk

Augmentin 3 x 1.2 g (3)

Cefazolin 3 x 2 g (3)

Ceftriaxone $2 \times 1 \mathrm{~g}(4)$

Cefazolin 3 x $2 \mathrm{~g}+$ Amikacin $\times 1 \mathrm{~g}(1)$

Ceftriaxone $2 \times 2 \mathrm{~g}+$ Metronidazole $2 \times 0.5 \mathrm{~g}$ (2)

Ceftriaxone 2 x $1 \mathrm{~g}+$ Amikacin $\times 1 \mathrm{~g}$ (1)

\section{Colo-rectal operations}

Augmentin 3 x 1.2 g (3)

Augmentin $3 \times 1.2 \mathrm{~g}+$ Metronidazole $2 \times 0.5 \mathrm{~g}$ (2)

Cefazolin 3 x $2 \mathrm{~g}+$ Metronidazole 2 x $0.5 \mathrm{~g}$ (5)

Ceftriaxone 2 x $1 \mathrm{~g}+$ Metronidazole $3 \times 2 \mathrm{~g}$ (1)

Cefazolin $3 \times 2 \mathrm{~g}+$ Amikacin $\times 1 \mathrm{~g}+$ Metronidazole 3 x $0.5 \mathrm{~g}(2)$

Augmentin $3 \times 1.2 \mathrm{~g}+$ Amikacin $\times 1 \mathrm{~g}+$ Metronidazole $3 \times 0.5 \mathrm{~g}(5)$

Ceftriaxone 2 x $1 \mathrm{~g}+$ Amikacin $\times 1 \mathrm{~g}+$ Metronidazole 3 x $0.5 \mathrm{~g}$ (1)

\section{EXPERTS' RECOMMENDATIONS}

\author{
Cefazolin/Cefoxitin
}

Cefazolin/Cefoxitin

PO neomycin + erythromycin, then

IV cefoxitin/cefotetan or

IV cafazolin + metronidazole
The audit 2003 showed a usage of different antibiotics of wide spectrum, and especially of the cephalosporins of III and IV generation, which are not among the accepted recommendations (and should be reserved for the therapy of infection, when appropriate).

After the audit, a literature search was performed and several world-wide accepted guidelines were reviewed [2, 3,
$15,20,22,23]$. Surgeons and microbiologists worked together and prepared a model of antibiotic policy in surgery, which was discussed with all colleagues. Written guidelines for surgical antibiotic prophylaxis and therapy were accepted. The control of compliance was performed by four 3-month audits which took place at the end of 2004/beginning 2005, 2006, 2007 and 2008.

Table 2. Summary of audits of antibiotic prescriptions 2004/5, 2006, 2007 and 2008

\begin{tabular}{|c|c|c|c|c|}
\hline & $2004 / 2005$ & 2006 & 2007 & 2008 \\
\hline Patients & $\begin{array}{l}\mathrm{N} 66, \text { of them }-32(19 \mathrm{M}, \\
13 \mathrm{~F}, 27-77 \text { year-old } \\
\text { (mean } 52.7)- \text { received } \\
\text { AB prophylaxis }\end{array}$ & $\begin{array}{l}\text { N 9; } 7 \text { Male: } 21-79 \text { year- } \\
\text { old, mean }(53.1), 2 \\
\text { Female: } 30-49 \text { year old, } \\
\text { mean }(39.5)\end{array}$ & $\begin{array}{l}\text { N 25; } 10 \text { Female, mean } \\
\text { age } 64 \text { (28-87); } 15 \text { Male, } \\
\text { mean age } 50.5 \text { (16-77) }\end{array}$ & $\begin{array}{l}\mathrm{N} 62 ; 38 \text { Male, mean } \\
\text { age } 60.4(28-85), 24 \\
\text { Female, mean age } 60.4 \\
(26-78)\end{array}$ \\
\hline Procedures & $\begin{array}{l}18 \text { clean - no AB; } \\
9 \text { preliminary contami- } \\
\text { nated; } \\
29 \text { clean-contaminated }\end{array}$ & $\begin{array}{l}4 \text { on emergency, } 5 \\
\text { elective; } 2 \text { clean, with } \\
\text { risk factors, } 3 \text { clean- } \\
\text { contaminated, } 2 \text { conta- } \\
\text { minated, } 2 \text { preliminary } \\
\text { contaminated }\end{array}$ & $\begin{array}{l}16 \text { elective, } 9 \text { emergent; } \\
5 \text { clean, } 10 \text { clean- } \\
\text { contaminated, } 2 \text { conta- } \\
\text { minated, } 8 \text { preliminary } \\
\text { contaminated }\end{array}$ & $\begin{array}{l}7 \text { clean, } 12 \text { clean- } \\
\text { contaminated, } 13 \text { conta- } \\
\text { minated, } 30 \text { preliminary } \\
\text { contaminated; } 42 \text { elec- } \\
\text { tive, } 20 \text { on emergency }\end{array}$ \\
\hline
\end{tabular}




\begin{tabular}{|c|c|c|c|c|}
\hline $\begin{array}{l}\text { The first most } \\
\text { common antibiotic } \\
\text { regimen }\end{array}$ & Cefazolin 3x2.0 IV (n 14) & Cefazolin 3-4 x 2 g I.V. & Cefazolin $3 \mathrm{x} 2 \mathrm{~g}$ & Cefazolin $3 \times 2 \mathrm{~g}$ \\
\hline $\begin{array}{l}\text { The second most } \\
\text { common antibiotic } \\
\text { regimen }\end{array}$ & $\begin{array}{l} \pm \text { Metronidazole } 2-3 \mathrm{x} \\
0.5-1.0 \mathrm{IV} / \text { Clindamycin } \\
2 \mathrm{x} 0.6 \mathrm{IV} \pm \text { Gentamicin } \\
0.160 \mathrm{IV}\end{array}$ & $\begin{array}{l}\text { + Metronidazole } 3 \times 0.5 \text { - } \\
1 \mathrm{~g} \mathrm{x} 2 \mathrm{~d} \pm \text { Gentamicin } 160 \\
\mathrm{mg} \mathrm{I.V}\end{array}$ & $\begin{array}{l}+\quad \text { Metronidazole } \\
3 \times 500 \mathrm{mg}\end{array}$ & $\begin{array}{l}+\quad \text { Metronidazole } \\
\text { 3x500mg } \pm \text { Gentamicin } \\
\text { 160mgAlternatives: : } \\
\text { Augmentin, Amikacin, } \\
\text { Clindamycin }\end{array}$ \\
\hline Positive comments & $\begin{array}{l}\text { Adherence to } \mathrm{AB} \\
\text { prophylaxis guideline }\end{array}$ & $\begin{array}{l}\text { Adherence to AB } \\
\text { prophylaxis guideline; } \\
\text { the price, availability in } \\
\text { hospital pharmacy } \\
\text { influence the choice }\end{array}$ & & $\begin{array}{l}\text { Choice of antibiotic } \\
\text { influenced by: } \\
\text { bactericide action, wide } \\
\text { spectrum, therapeutic } \\
\text { wideness, price, } \\
\text { availability in pharmacy }\end{array}$ \\
\hline Negative comments & $\begin{array}{l}3 \text { patients }(9.4 \%) \\
\text { needed prophylaxis, but } \\
\text { it was not provided }\end{array}$ & $\begin{array}{l}\text { AB prophylaxis } \\
\text { continued as therapy: } \\
\text { 4-10 days, but with risk } \\
\text { factors }\end{array}$ & $\begin{array}{l}\text { Ceftriaxone used in } 2 \\
\text { Cefepime - in } 1 \text { cases; } \\
\text { length of prophylaxis } \\
\text { beyond } 2 \text { days }\end{array}$ & $\begin{array}{l}\text { Ceftriaxone used to } \\
\text { treat } S \text {. aureus infec- } \\
\text { tion; the timing in AB } \\
\text { prophylaxis not regu- } \\
\text { larly recorded }\end{array}$ \\
\hline
\end{tabular}

In order to focus the surgeons' attention on the accepted antibiotic policy, in 2007 - Antibiotic prophylaxis in surgery (SAP)-inquiry was performed, 19 colleagues participated. Figures 4-6 inform about the percentage of positive replies to three representative questions.

Fig. 4. Surgical antibiotic prophylaxis should be applied:

A. At the beginning of operation; B. Up to 30 minutes before the incision; C. Up to $60 \mathrm{~min}$ before the incision; D. Up to 2 hours before the incision

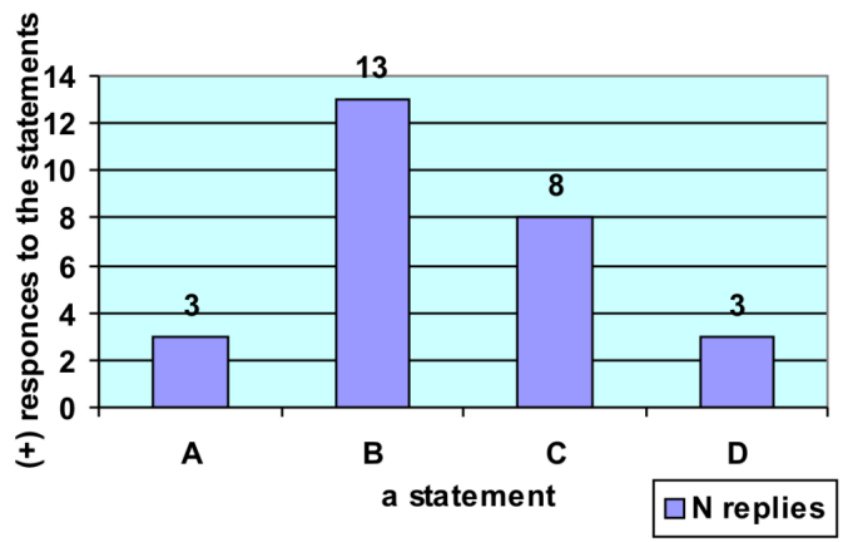
up to:

Fig. 5. Surgical antibiotic prophylaxis should continue
A. 24 hours;
B. 2 days;
C. 3 days;
D. 5 days

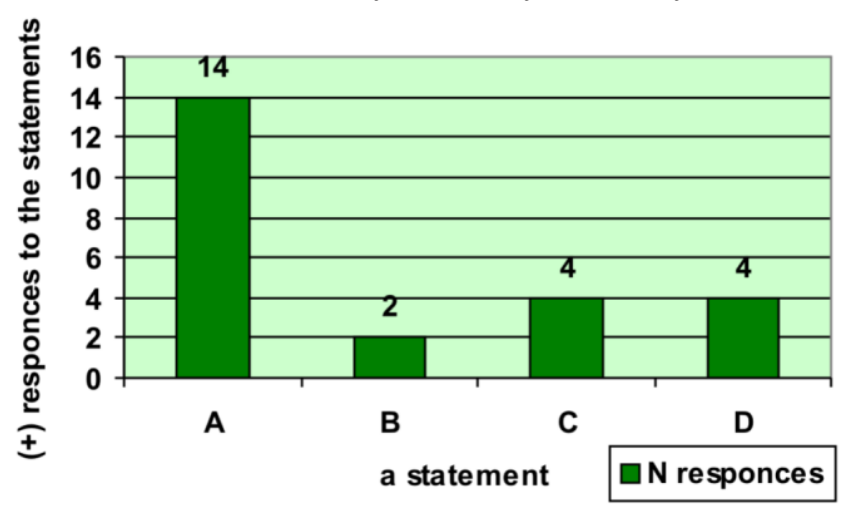

Fig. 6. What kind of operative procedures require antibiotic prophylaxis?

A. Clean; B. Clean-contaminated; C. Contaminated; D. Preliminary contaminated

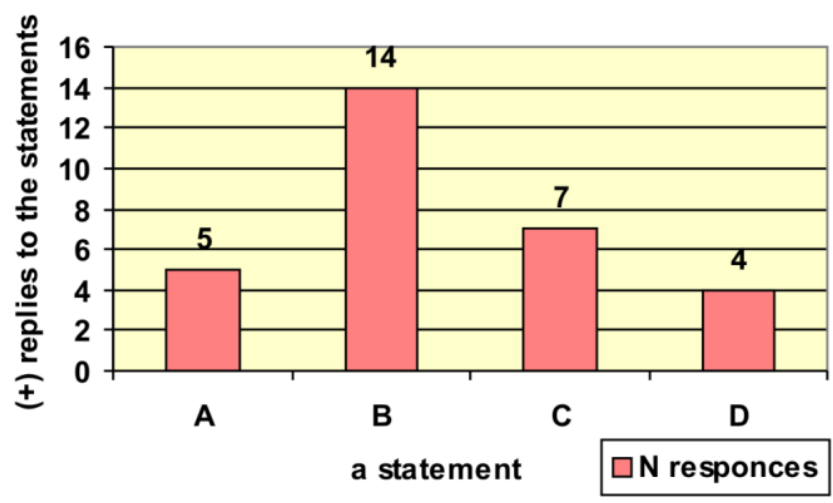


The results revealed that most of the personnel are well informed, although 4 people answered that the prophylaxis may continue 3 days, and other 4 - 5 days!

The second Inquiry took place in connection of the $18^{\text {th }}$ November 2009 - which was announced by the WHO and the ECDC as an antibiotic day. Nineteen surgeons participated. The main questions and the corresponding answers are presented in the figures 7 to 11 .

Fig. 7. Why antibiotics should be prescribed rationally?

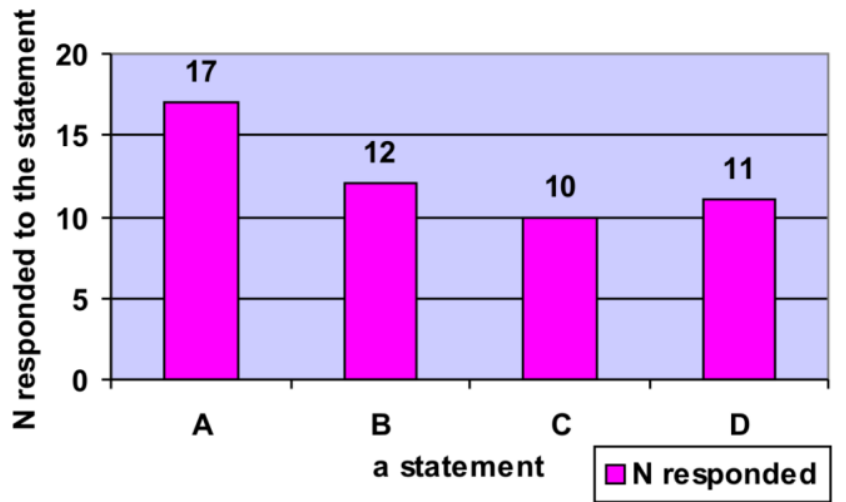

A. Resistance to $\mathrm{AB}$ develops and spreads quicklym B. Already there are pan-resistant organisms; C. Pharmaceutical industry needs $15-20$ years to introduce new $\mathrm{AB}$;

D. Resistance has social consequences

Fig. 8. What should be considered in antibiotic prescribing?

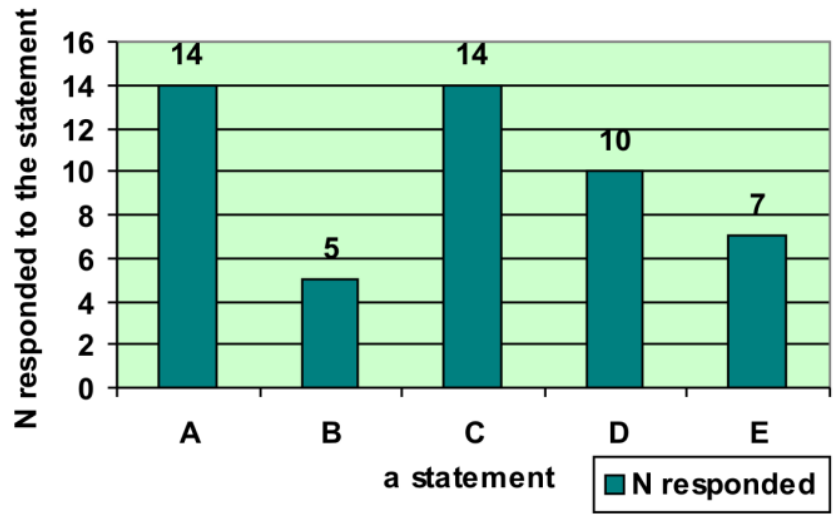

A. Spectrum of activity of the antibiotic; B. Mechanism of action; C. Effect: bactericidal/ bacteriostatic;

D. Therapeutic width; E. Pk/Pd
Fig. 9. Development of antibiotic resistance is due to:
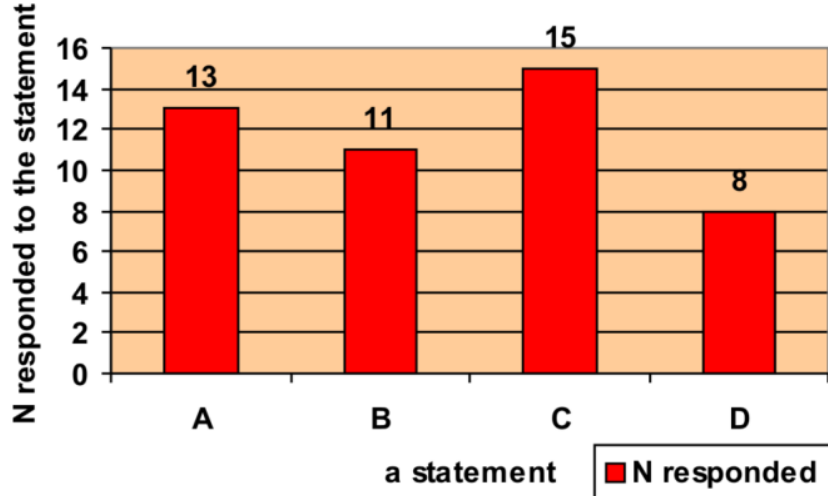

A. Mutations; B. Epidemic spread of bacterial plasmids;

C. Selection of resistant strains by the AB pressure;

D. Epidemic spread of microorganisms

Fig. 10. Which are the problem antibiotic resistant organisms in our institute?

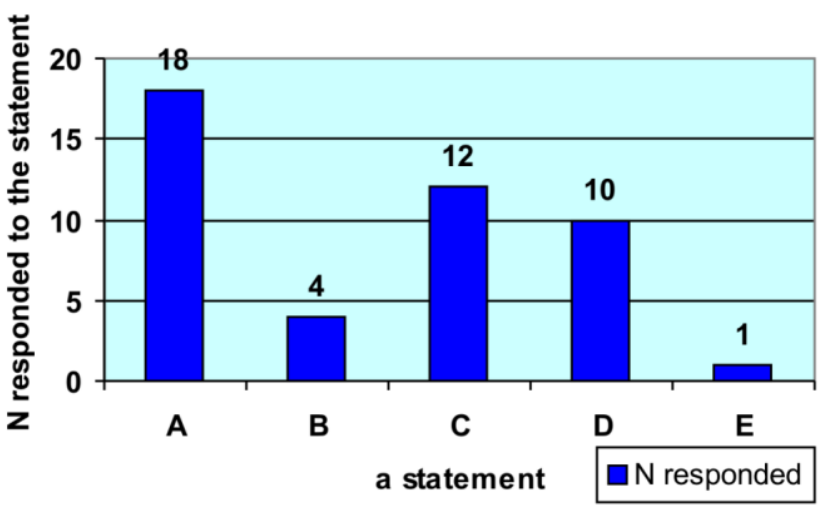

A. MRSA; B. PNSSP (penicillin-non-susceptible $S$. pneumoniae); C. ESBL-producing Enterobacteriaceae

D. MDR P. aeruginosa; E. $\mathrm{Cl}$. difficile

Fig. 11. Which are the main measures in the Infection control? (addressed to the nurses)

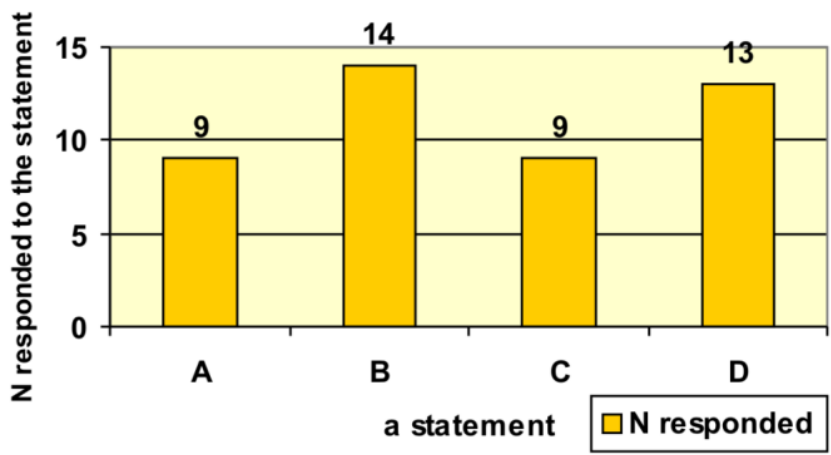

A. Hand washing; B. Good hygiene, disinfection, sterilization; C. Contact precautions; D. Screening for Antibiotic-Resistant organisms of patients 
This inquiry revealed that the personnel of the Surgery clinic is well informed about antimicrobial resistance - related issues.

\section{DISCUSSION}

The results of Antimicrobial Resistance Surveillance (Fig. 1-3) identified the problem about antibiotic resistant microorganisms at the Surgery clinic during the last four years as: MRSA (between $10 \%$ and $36 \%$ ), ESBL-producing Enterobacteriaceae (between $14 \%$ and $23 \%$ ) and MDR $P$. aeruginosa (30\% to $47 \%)$. These rates of resistance correspond to the national level [12] and are quite embarrassing, posing problems in therapy of infections.

Antibiotic consumption is another tool in assessing antibiotic policies. It was shown (Table 1) that the total antibiotic usage in the Surgery clinic was from 47.9 to 61.9 DDD/100 bed-day, which, although comparable with similar clinic in the similar geographical/socio-economical area, should be assessed as high. The higher usage of cephalosporins of first generation and imidazoles is related to their usage in therapy and prophylaxis of infections.

The first audit of antibiotic prescriptions, undertaken in 2003, has revealed usage of different antibiotics of wide spectrum, and especially of the cephalosporins of III and IV generation, which are not among the accepted recommendations (and should be perceived for the therapy of infection, when appropriate). On the contrary, the next four audits (Table 2) have clearly demonstrated the complete adherence to the institutionally accepted guidelines. For comparison, in other studies, the rate of inappropriate antibiotic usage in surgery was higher (Hacettepe UH, Turkey, $1994-28 \%$; LDS hospital, Salt Lake City, UT, 1985$1986-60 \% / 42 \%$ (timing of prophylaxis); $27-54 \%$ incorrect timing in 2651 patients from 44 hospitals in New York State, USA, $1995 ; 84 \%$ to $90.5 \%$ of 440 patients in Naples, Italy, 1996, received non-standard antibiotics; in Cornell University, NY, USA, 1998, 156 patients (74 \%) of the studied 211, have received inappropriate regimen (excessive duration, incorrect timing, incorrect spectrum or premature switch from I.V. to P.O.; 17 different antibiotics were used for prophylaxis and 21 for therapy ) [8 ]. In their study van Kasteren et al, 2003 [25 ] found a concordance with accepted policies in Dutch Orthopedic departments $43 \%$ for the dosing interval and 50 $\%$ for timing, while the compliance with antibiotic choice, duration and dose was respectively $92 \%, 82 \%$ and $89 \%$. In several more recent articles the authors had similar findings $[10,16,17,19,24$ ]: e.g. Miliani et al [17 ] in 2009 revealed non-compliance with recommendations generally with the duration of antibiotic regimen (65\%). Most of authors explained non-adherence is due to the fact, that doctors were not aware about the current policies (not informed, not distributed, too many variants etc). In our institute we consider the adherence of surgical personnel is related most probably to the co-authorship in preparing guidelines and the comprehensive discussion before the acceptance.

Although experts recommend interventions as main measures in improving antibiotic policies, we should say, that in our experience we do not achieved all tasks: we wanted to study the reasons for antibiotic choice, but only a few surgeons have filled in this part of the questionnaire: the commonest answers were: because the particular antibiotic was bactericidal, with high therapeutic wideness, of broad spectrum, non-expensive, available in the hospital pharmacy. Also, some of the forms were filled in formally, without the exact timing or dosing regimen, and were not appropriate for evaluation.

\section{CONCLUSIONS}

This study showed several important characteristics of the usage of antibiotics in a Surgery clinic.

The problem antibiotic resistant organisms during the period 2006-2009 were MRSA, ESBL-producing Enterobacteriaceae and multiple-drug - resistant $P$. aeruginosa, their rate corresponded to the national surveillance rate.

The Antibiotic consumption in the clinic was from 48 to $62 \mathrm{DDD} / 100$ bed-day, which should be evaluated as middle to high. Cephalosporins of first generation were the most applied antibiotics (antibiotic prophylaxis, therapy of staphylococcal infections).

The current antibiotic policy was instituted after a wide discussion in 2003. Four 3-month Antibiotic audits were performed thereafter to control the practice and evaluate the adherence: they revealed a substantial improvement in antibiotic prescribing: cefazolin \pm metronidazole were the commonest regimens in abdominal and septic surgery, cephalosporins of higher generation were avoided. Two drawbacks were emphasized: sometimes a higher duration of prophylaxis; the timing in antibiotic application was not recorded in some questionnaires.

One important achievement was the compliance of the surgical personnel with the institutional antibiotic policies, which should be attributed to the co-authorship in guidelines. The positive attitude towards the rational prescription of antibiotics and considerable knowledge on antimicrobial resistance were demonstrated in the two inquiries. In comparison with other studies, the adherence of our personnel to the antibiotic policies in place was higher. 


\section{REFERENCES:}

1. Antibiotic policy in Surgery 2003 (project). 2003. International Society of Chemotherapy, Surgical Infection SocietyEurope, Interregional Association for Clinical Microbiology and Antimicrobial Chemotherapy, All-Russian Scientific Medical Surgeons' Society

2. Antibiotic prophylaxis in Surgery. A national clinical guideline SIGN. www.sign.ac.uk

3. Antimicrobial prophylaxis in Surgery. 2002. The Medical Letter, 43, 92-97

4. Barie PS, Patchen Dellinger E, Ellner JJ, McGowan JE. 2007. Maximizing Nosocomial Infection Management With Newer Therapeutic Approaches and Techniques In An Era of Increasing Microbial Resistance: A Surgical Perspective. MedScape

5. Bedouch P, Labarere J, Chirpaz E et al. 2004. Compliance With Guidelines on Antibiotic Prophylaxis in Total Hip Replacement Surgery: Results of a Retrospective Study of 416 Patients in a Teaching Hospital. Infect Control Hosp Epidemiol, 2004 Apr;25(4):302-7.

6. Dellit TH, Owens RC, McGowan JE et al. 2007. Infectious Diseases Society of America and the Society for Healthcare Epidemiology of America guidelines for developing an institutional program to enhance antimicrobial stewardship. Clin Infect Dis; 44: 159-177

7. Dryden MS, Cooke J, Davey P. 2009. Antibiotic stewardship - more education and regulation not more availability? J Antimicrob Chemother, 64, $5,885-888$

8. Erdal Akalin H. 2002. Surgical prophylaxis: the evolution of guidelines in an era of cost containment. J Hosp Infect. 50, suppl A: S3-S7

9. Fishman NO. 2010. Antimicrobial Stewardship is Vital to Avoid a Return to the Preantibiotic Era. CDC expert commentary, MedScape

10. Hosoglu S, Aslan S, Akalin S, Bosnak V. Audit of quality of perioperative antimicrobial prophylaxis. Pharm Word Sci, 2009 Feb;31(1):14-7. Epub 2008 Nov 26

11. IDSA. 2004. Bad Bugs - No Drugs. (www.fda.gov)

12. Kantardjiev T. 2009. Laboratory surveillance of infections in Bulgaria. Microbiologia Balkanika 2009, 6th Balkan Congress of Microbiology, Abstract Book, p 104, 5.2

13. Keuleyan E, Gould IM. Key issues in developing antibiotic policies: From an institutional level to Europe-wide. European Study Group on Antibiotic Policy (ESGAP), Subgroup III. Clin Microbiol Infect. 2001;7:16-21.

14. Lipsky BA, Weigelt JA, Gupta V, Killian A, Peng MM. Skin, Soft Tissue, Bone and Joint Infections in Hospitalized Patients: Epidemiology and Microbiological, Clinical, and Economic Outcomes. Infect Control Hosp Epidemiol. 2007 Nov; 28(11):1290-8. Epub 2007 Oct 3.

15. Mangram AJ, Horan TC, Pearson ML Silver LC, Jarvis WR. 1999. Guideline for Prevention of Surgical Site Infection, 1999. Hospital Infection Control Practices Advisory Committee. Infect Control Hosp Epidemiol: 1999 Apr;20(4):250-78; quiz 279-80.

16. McCahill LE, Ahern JW, Gruppi LA et al. Enhancing Compliance With Medicare Guidelines for Surgical Infection Prevention. Arch Surg. 2007 Apr;142(4):355-61.

17. Miliani K, L'Heriteau F, Astagneau P, INCISO Network Study Group. Noncompliance with recommendations for the practice of antibiotic prophylaxis and risk of surgical site infection: results of a multilevel analysis from the INCISO Surveillance Network. J Antimicrob
Chemother, 2009 Dec;64(6):1307-15. Epub 2009 Oct 16.

18. Patchen Dellinger E, Gordon S, Wenzel RP. 2010. Prevention of SurgicalSite Infections: Best Practices, Better Outcomes. http://www.medscape.org/ viewarticle/720011

19. Rapp RP. Practice Guidelines for Implementing Antimicrobial Stewardship. 41 st ASHP Midyear Clinical Meeting Anaheim Orange County, CA

20. Societe Francaise d'Anesthesie et de Reanimation. 1999. Guidelines for antibiotic prophylaxis in surgery: update 1999 (in french). Med Malad Infect, 29: 435-445

21. SMAC. 1998. The Path of Least Resistance. London, Department of Health

22. Strachunskii LS, Rozensson OL. 2002. Antibiotic prophylaxis in Surgery. Pp 276-278 In: LS Strachunskii, UB Beloussov, SH Kozlov (Eds). Practical Manual on Antimicrobial Chemotherapy. Moscow (in Russian)

23. Talbot TR, Kaiser AB. 2005. Postoperative Infections and Antimicrobial Prophylaxis. Pp 3533-3546 In: Mandel, Douglas and Bennett's Principles and Practice of Infectious Diseases. $6^{\text {th }}$ Ed, Elsevier Churchill Livingstone

24. Tourmosoglou CE, Yiannakopoulou ECh, Kalapothaki V, Bramis J, Papadopoulos JSt. Adherence to guidelines for antibiotic prophylaxis in general surgery: a critical appraisal. J Antimicrob Chemother, 200861 (1): 214-218.

25. Van Kasteren MEE, Kullberg BJ, de Boer AS, Mintjes-de Groot J, Gyssens IC. Adherence to local hospital guidelines for surgical antimicrobial prophylaxis. J Antimicrob Chemother, 2003 51(6): 13891396

26. Western Australian Therapeutic Advisory Group. 2008. Surgical Antibiotic prophylaxis.
Address for correspondence:

Assoc. Prof. Emma Keuleyan, PhD

Head, Department of Clinical Microbiology,

Medical Institute - Ministry of the Interior

79, Skobelev Blvd., Sofia 1606, Bulgaria

Phone: +3592 9821 451, Fax: +3592 954 2875;

E-mail: emma_keuleyan@yahoo.com 